\title{
Schopenhauer and Habermas \\ on Negative Understanding of Justice: Interdisciplinary Approach
}

\author{
Alexey I. Trotsak* \\ The Immanuel Kant Baltic Federal University \\ 14 Nevskogo, Kaliningrad, 236041, Russia
}

Received 26.12.2015, received in revised form 26.02.2016, accepted 04.07.2016

The purpose of this paper is to raise a question on building a just society through the interdisciplinary analysis of A. Schopenhauer and J. Habermas's systems. The article offers historical and philosophical analysis of the concept of 'justice'. In order to understand the connection between these two systems (Schopenhauer's and Habermas's) and modern issues of building a just society, it is touched upon the institutional theory and the status of justice within this theory, thereby showing how difficult the understanding of justice can be for both kinds of interdisciplinary knowledge - philosophy and economy - if initial synthesis is not taken into account.

Keywords: justice, Habermas, Schopenhauer, institutions and institutional analysis.

DOI: 10.17516/1997-1370-2016-9-9-2131-2138.

Research area: philosophy.

\section{Introduction}

At first glance, it can be assumed that there is no direct link between the philosophy of A. Schopenhauer and J. Habermas. Firstly, Habermas, by his own admission, felt himself the impact of Hegelian-Marxist philosophy. Secondly, he rethought Kant's moral philosophy in order to apply it to the theory of communication and law (Habermas, 1995, 105). In other words, Schopenhauer's system was not a primary source in Habermas's research. Assuming the absence of direct philosophical continuity between Schopenhauer and Habermas, we should not forget that the mentor of Habermas - Theodor Adorno referred to some elements of Schopenhauer's system, he used Schopenhauer's criticism of Kant's philosophy and perceived Schopenhauer through the philosophy of Friedrich Nietzsche (Adorno, 1983). All this could not be ignored by Habermas who was 'spinning' in the whirl of philosophical ideas of the Frankfurt School.

However, we are mostly interested not in the historical continuity between the schools but in the continuity of a particular problem that was acutely posed by Schopenhauer in "The World as Will and Representation" and in the contest essay "On the Basis of Morality". This problem is the negative understanding of justice and the complexity of building full-fledged and just human society. For Habermas as a representative

(C) Siberian Federal University. All rights reserved

* Corresponding author E-mail address: aleksei_trocak@mail.ru 
of $\mathrm{XX}$ century, this problem acquired special urgency because the development of the capitalist society had faced unmanageable obstacles in social and economic aspects. So it is impossible to solve these problems without turning to the issue of building a just society.

It is worth mentioning that by the notion of 'just society' we understand a certain institution in which each member is endowed with equal rights and bears moral and legal responsibility for himself and other people. In addition, we believe that the phenomenon of justice has ethical and moral grounds. In other words, it depends on the system of moral norms which are followed by the subject.

\section{Link between Schopenhauer's principle 'neminem laede' and Habermas's Theory of Communicative Action}

It was unacceptable for Schopenhauer's philosophy to search for the source of society existence in happiness or pleasure. On the contrary, a key aspect of his ethics is an assertion that "all the world is full of suffering" (Schopenhauer, 2004, 458). For this reason, Schopenhauer considers happiness and pleasure as negative states because they are aimed at the abolition of suffering. From this point of view, suffering is positive as it helps us recognize pleasure (Schopenhauer, 2004, 451).

The relationships among people are based on the phenomenon of compassion which in its generalized version corresponds to the Vedic formula: 'Tat tvam asi'. This phenomenon is also called the 'golden rule' of morality. Schopenhauer considers compassion as a moral and valuable phenomenon which is rewarded to everyone by nature. In other words, there is no need to prove this 'principle' - it exists in everyone. Compassion in frames of its system acts as a priori and posteriori form. Therefore, compassion rests on feelings and at the same time corresponds to norms. Professor

M. Kossler also emphasizes this duality:

However, it does not mean that norms are unnecessary. The number of them is just as small as the number of examples of fair living together. In ethics there is no refusal of maxims' application. But some moral and ethical actions do not depend on the observance of norms (Kossler, 1999, 474)'.

A possible paradoxical situation, which stems from Schopenhauer's claims, corresponds to the following questions: what is the way to regulate the behavior of people based solely on the principle of compassion? Is it enough to refer only to this praphenomenon? Schopenhauer says:

Justice restrains me from inflicting suffering upon another, i.e. producing something which does not exist yet, becoming a cause of other people's sorrows (Schopenhauer, 1900, 241).

Thus, Schopenhauer declares the principle of legal justice a sufficient category which underpins the principle of compassion in the 'neminem laede' form ('do harm to no one'):

Since the demand for justice is purely negative, its fulfilment can be forced because the rule "neminem laede" can be followed by all together. A forcing institution is represented by a state whose sole aim is to protect individuals both from one another and from external enemies (Schopenhauer, 1900, 242).

It is worth mentioning that Schopenhauer regards law as only a part of morality; therefore, morality takes precedence over the law 
(Schopenhauer, 1900, 243). In fact, the virtue of justice relates to the duties of law while the humanity corresponds to the duties of virtue which are enclosed all together in the principle of compassion. In this case the state, according to Schopenhauer, should provide its citizens with freedom of morality because the laws of the state have only positively legal character. However, the idea of state creation is natural like the principle of compassion itself. State laws stem from experience and by means of this experience. The very idea of state formations is a priori notion of pure reason, as well as the virtue of justice. In such state structure the virtue of justice has a negative characteristic as it does not allow any actions aimed at suppressing human rights by means of the law, on the one hand, and the theory of pure law and morality, on the other (Schopenhauer, 1900, 242).

What does Habermas suggest? Proceeding from the understanding of Kant's categorical imperative, he looks for a generally valid rule or tool for the establishment of coordination between agents. In particular, he does not accept the 'golden rule', which was largely applied in the history of philosophy as a basis for the ethical theory. Habermas, in fact, repeats Kant's critique according to which the 'golden rule' expresses an individual will. It cannot be meaningful for everyone and, therefore, be suitable for theoretical application (Habermas, 1999, 75). Hence, the basic hypothesis of discourse ethics is "the application of the correctly understood universal basic principles" (Habermas, 1999, 75). The possibility to universalize these basic principles of ethics, as well as intersubjectivity, serves for Habermas as a main instrument in an attempt to justify his theory of communication.

Unlike Schopenhauer, Habermas does not consider justice as virtue, although justice and solidarity act as such categories in Habermas's philosophy which contribute to the constructive interaction of the agents who communicate between each other. This statement is based on relevant arguments. Firstly, Habermas believes that the issue of justice should not be considered as an abstract category:

Philosophical discourse on justice does not reach the institutional dimension which has been a basis for public discourse on law from the very beginning. If the law is not considered as a system which is based on empirical actions, philosophical concepts remain empty (Habermas, 1998, 90).

Secondly, Habermas considers the category of justice apart from the notion of good highlighting the ethical and moral constituent:

Discourse ethics regulates ethical and moral issues in accordance with various forms of argumentation, i.e., on the one hand, the discourse itself, and, on the other, the discourse of justification and application of the norms. However, morality is not thereby reduced to a common approach, it includes both aspects - the understanding of justice as solidarity and consideration [of opinions] (Habermas, 1999, 50, 51).

Thirdly, Habermas thinks that normative moral theories, which act as a stronghold of justice in some culture, have exhausted themselves. One of the recent attempts to construct such a theory was made by Rawls:

According to Rawls, it [theory of justice] is represented as a weak [theory] which is underpinned only by the formal understanding of good and a number of normative statements which have fragmented nature (Habermas, 1998, 84)². 
Habermas does not speculate in the framework of the traditional moral philosophy which is characterized by a well-known Kantian language. He does not seek the inside 'spring' in a person which was common in Classical German philosophy. For Habermas it is rational discussion of the problem, i.e. the ability to speak out and take everyone's opinion into account which bears importance:

The principle of discourse ethics makes every kind of normative act dependent on unanimous consent... The question of how the principle of discourse can be applied to behavioral norms that are governed by an unlimited range of recipients acting in a simple interaction depends on a certain type of discourse. In other words, it corresponds to the form of moral argumentation (Habermas, 1998, 196).

However, in our opinion, discourse ethics loses its significance in pursuit of rationality. Habermas is, in fact, in a quandary: he does not offer any moral law focusing only on the analysis of the law. In this case morality has only an instrumental function. The notion of publicity, which Habermas tries to expose as an argument in favour of discourse ethics, is directly reflected in Kantian understanding of the transcendental principle of the law formulated by this Königsberger in the essay "Toward Perpetual Peace". If Kant wanted to show by this principle the possibility of exposing a policy-liar by means of public recognition, i.e. to withdraw the law from morality and highlight the priority of moral norms, Habermas focuses only on legal aspects of existence of individuals by means of the language. In our opinion, this is not enough for searching the cause of human actions. However, Habermas himself does not pursue a similar goal. To this end, the following questions arise: what are the law and communication based on? If not on motives and actions, do they rest on the sphere of morality?

In their time analytic philosophy and partly phenomenology hid purely moral issues and replaced them with formal and logical procedures. However, there are no grounds for saying that the relationship between the philosophy of Schopenhauer, as one of the last representatives of the German classical philosophy, and Habermas has been broken. On the contrary, it seems possible to perceive the relationship between the models of both philosophers through the analysis of the 'neminem laede' principle.

Schopenhauer's principle of 'neminem laede' which characterizes the virtue of justice acts as a limiter of human communication. The law limits the performing of illegal acts, it imposes punishment for entailed consequences and warns a person by means of fear. As the basis of the law, morality in its turn motivates human behavior in such a way that it does not allow inflicting suffering on other people. Causing no other injustice to another person in the framework of morality is active in nature, while justice in the course of the law is characterized as passive. The core of Schopenhauer's moral philosophy is revealed in compassion which acts as the very first form of humanity. It dulls selfish motives of a subject and induces him to sociability. Taken separately, the principle of justice based on the 'neminem laede' can lead to the excessive 'care' of a state towards its citizens. Likewise Habermas, Schopenhauer argues against such intervention. According to Schopenhauer, the principle of compassion and the virtue of justice serve as a link for the organization of human behavior and communication.

The key difference between philosophers is their relation to a person in general. If Schopenhauer places excessive demands on an individual by dividing people into geniuses and 
commoners, Habermas in his turn does not focus on individual characteristics of the subject treating them as purely the media of rationality. Thus, a legitimate question arises: who can be considered as a full member of communication bearing the characteristics of rationality, education, and morality? In order to answer this question, it is necessary to recall Kant's idea of sentient beings in general, without taking into account only the representatives of the human race.

So Habermas, like Schopenhauer, is forced to occupy a critical position of considering both the world as a whole and a certain society in particular. However, while the criticism of the current regime and injustice between states is regarded by Habermas as a field of search for consensus, for Schopenhauer it eventually turns into pessimism which is revealed in an attempt to deny the will to live. Justice in this case remains the category which brings the philosophy of both Schopenhauer and Habermas together by uniting them within initial assumptions. But it is not only the philosophy of morality and law which develops the question of justice. Nowadays some economic models connect interactions between market subjects directly with the notion of justice. Therefore, we can notice an indirect link between modern economic processes and the philosophy of morality, i.e. the philosophy of Schopenhauer and Habermas.

\section{The need to correct} modern understanding of justice

Relatively speaking, modern economic thought corresponds to the model of Habermas more than to the philosophy of Schopenhauer. The basic premise of microeconomics rests on the assumption that the company, as a market agent, functions on the basis of rational behaviour. The agents operate in accordance with the desire to maximize their profits and minimize production costs. The market, therefore, is a space for communication or the meeting between a seller and a buyer. Moreover, the conclusion of the contract is accompanied by the transmission of property rights from one subject to another (Nureev, 2002, 80). In this case the economy is closely related to the law which in its turn rests (although remotely) on the principles of morality. When the transmission of property rights is carried out, the problem of transaction costs, i.e. the costs in the exchange sphere, arises.

Until the second half of XX century the minds of economists were occupied only with the notion of transformation costs, i.e. those costs which are aimed at the physical transformation of a particular good. However, no one took into account significance of transaction costs until the emergence of the work "The Nature of the Firm" (1937) by Ronald Coase. Professor A. Nesterenko (Nesterenko, 2002, 250) defines such costs as "the costs connected with gaining information, settlement of transactions and protection of property rights".

Coase introduced not only the notion of transaction costs, but also a hypothesis of the world with zero transaction costs. He wanted to show that classical economics works smoothly without these costs. It is worth mentioning that such situation is impossible in the modern world; the costs for the search for information about suppliers, customers, and distribution markets will always exist. Coase in his turn understood it perfectly well. His hypothesis only highlighted the impossibility of considering modern market society without examining its transactions. We will not go into the purely economic aspects of this theory, we will emphasize only the moments significant for our analysis. Coase was one of the economists who analyzed the relationship between economics and law:

It is necessary to know whether the damaging business is liable or not for damage caused 
since without the establishment of this initial delimitation of rights there can be no market transactions to transfer and recombine them. But the ultimate result (which maximises the value of production) is independent of the legal position if the pricing system is assumed to work without cost (Coase, 1960, 99).

We believe that in an ideal situation when there are no costs, the absence of law may provoke a situation when economic agents would act according to the most efficient way of solving economic problems, for instance, by immoral means, if we take into account the argumentation of Schopenhauer (Schopenhauer, 1900, 235) about the first selfish 'spring' inside a human. In this case there are not any signed contracts because some agents will not be completely satisfied. A similar argument was advanced by Samuelson; Coase in his turn agreed with this argument adding that there are very few similar cases as economic agents should be able to think intelligently.

Taking into account transaction costs in the world, we need to have and at the same time rely on tools which maintain the agreed exchange, i.e. on the property institution which in its turn is based on a particular understanding of the phenomenon of justice. Some types of transaction costs, acknowledged by many economists, only emphasize therelationship between economics and law, i.e. the costs for conducting and concluding negotiations, the protection of property rights, and the protection against opportunistic behavior. All of them go through the communication of subjects. Special attention should be paid to the costs of opportunistic behavior. They are based on the divergence of subjects' interests due to finite resources, the uncertainty of contract specifications. Therefore, from the perspective of the contract process, there are two types of such behavior - pre-contract and post-contract. The reduction of opportunistic costs differs from country to country; it depends on the transparency of procedures in political and legal spheres which are characterized by clear mechanisms for contract enforcement. In addition, it is impossible to understand why these opportunistic costs are driven only by the economy. In this case the aid should come in the form of moral philosophy.

Thus, a quick overview on the current economic situation highlights once again the importance of an interdisciplinary approach to the analysis of the phenomenon of justice and the possibility of building a just society.

Firstly, the study of the market agents behavior is directly based on the problem of motivation and action, i.e. such an action which is aimed at the process of sharing. In this case civil society should operate on the basis of maintaining just order for economic activity. Secondly, the theory of transaction costs has demonstrated the need for a link between economics and law at the analysis of the problems of property institution which 'loop' again on the phenomenon of justice.

However, one problem still remains on the agenda. There is no universally valid theory of justice. Tackling the problems of the economy in this section only encourages solving this purely philosophical problem. But, as we see, within the scope of economy, the notion of justice resembles, in some sense, an 'axiom' that cannot be explained directly. In any case, its proof falls on the shoulders of philosophers.

Unlike Schopenhauer, Jürgen Habermas is familiar with the issues of the economy and tends to consider actively social problems. In this sense, his works "Aus Katastrophen lernen?", "Was ist Volk?", "Die postnationale Konstellation und die Zukunft der Demokratie" and many others allow us to critically reconsider the past. However, the problem of building a just society in our time 
still remains unsolved because there is still a dilemma in our society: how to build interaction between people? Shall we establish institutions based on laws (forced and prescribed) or on rights (voluntary created)? In our opinion, the problem of building a just society will not be solved if only the premises of law are taken into account. The law does not function to the full extent unless it relies on a clearly articulated theory of morality. Habermas's theory of communication can be of use only at the critical analysis of this problem. However, the final solution remains open. In Schopenhauer's system we can observe the convergence of the philosophy of morality and law. From this point of view, morality is endowed with priority which, in our opinion, plays a vital role in the understanding of the phenomenon of justice. However, a negative result of Schopenhauer's system presented in the form of pessimism cannot seem productive for the solution of social problems. In any case, both theories of the philosophers mentioned above can interact with each other on the principle of complementarity without engaging in systemic conflict.

We should highlight once again that without interaction with the philosophy both the economy and policy cannot solve fundamental questions of human existence including the problem of justice.

$1 \quad$ Here and further translated from Russian and German into English by Author.

2 Debates about Habermas and Rawls see in: Habermas and Rawls: Disputing the Political (2011). Edited by James Gordon Finlayson and Fabian Freyenhagen, Routledge, Taylor \& Francis, 316 p.

\section{References}

Adorno, Theodor W. (1983). Probleme der Moralphilosophie, Suhrkamp Verlag, herausgegeben von Thomas Schröder, $317 \mathrm{p}$.

Coase, R. (1960). The Problem of social Cost, The Journal of Law and Economics, Vol. III, October, 1-44.

Habermas, J. (1995). Demokratija. Razum. Nravstvennost'. [Democracy. Mind. Moral], Academia, KAMI, Moscow, 245 p.

Habermas, J. (1998). Faktizität und Geltung: Beiträge zur diskurstheorie des Rechts und des demokratischen Rechtsstaats, Suhrkamp Verlag, Frankfurt am Main, 667 p.

Habermas, J. (1999). Die Einbeziehung des Anderen: Studien zur politischen Theorie, Suhrkamp Verlag, Frankfurt am Main, 404 p.

Habermas and Rawls: Disputing the Political (2011). Edited by James Gordon Finlayson and Fabian Freyenhagen, Routledge, Taylor \& Francis, 316 p.

Koßler, M. (1999). Empirische Ethik und christliche Moral: zur Differenz einer areligiösen und einer religiösen Grundlegung der Ethik am Beispiel der Gegenüberstelung Schopenhauers mit Augustinus, der Scholastik und Luther, Königshausen und Neumann, Würzburg, 517 p.

Nesterenko, A. N. (2002). Ekonomika [Economics], In Nesterenko A. N. Ekonomika i institucional'naya ekonomika [Economics and institutional Economics], Editorial URSS, Moscow, 209 - 273.

Nureev, R. M. (2002). Kurs mikroekonomiki [Study Guide in Microeconomics], Izdatel'stvo Norma [Norma Publishing], Moscow, 572 p.

Schopenhauer, A. (1900). Preisschrift über die Grundlage der Moral, In Arthur Schopenhauers sämtliche Werke in zwölf Bänden, VII Band, J. G. Cotta'sche Buchhandlung Nachfolger, Stuttgart und Berlin, 137-298. 
Schopenhauer, A. (1996). Die Welt als Willle und Vorstellung, Bd. 2, Reclam, Stuttgart, 869 p.

Schopenhauer, A. (2004). Die Welt als Willle und Vorstellung, Bd. 1, Reclam, Stuttgart, 736 p.

\title{
Шопенгауэр и Хабермас \\ о негативном понимании справедливости: междисциплинарный подход
}

\author{
А.И. Троцак \\ Балтийский федеральный университет \\ им. Иммануила Канта \\ Россия, 236041, Калининград, ул. Невского, 14
}

Целью данной статьи является постановка вопроса о построении справедливого общества посредством применения междисииплинарного подхода, основываясь на системах А. Шопенгауэра и Ю. Хабермаса. Предлагается использовать исторический и философский анализ понятия “справедливость”. Автор исходит из предположения, что существует связь двух философских систем (Шопенгауэра и Хабермаса) с современной моделью построения справедливого общества. Тем самым затрагиваются вопросы институциональной теории и справедливость рассматривается в качестве предмета междисииплинарного знания: философии и экономики.

Ключевые слова: справедливость, Хабермас, Шопенгауэр, институты и институциональный анализ.

Научная спещиальность: 09.00.00 - философские науки. 